\title{
Desire and Drive in Researcher Subjectivity: The Broken Mirror of Lacan
}

\author{
Tony Brown \\ Manchester Metropolitan University
}

\begin{abstract}
This paper offers an account of how a researcher's subjectivity might be seen as being stitched into the fabric of practitioner research. It utilizes Lacan's notion of the mirror phase in suggesting that the subject of reflection is not quite what she might seem to be. The Freudian concept of desire is considered in relation to the motivations that reflective research models produce. This is contrasted with his concept of drive read against a research attitude where excessive belief in the linguistic forms of such research risks usurping the life they might seek to locate. The paper draws on a contemporary reading of the terms as offered by the Lacanian social commentator Slavoj Žižek. Two examples are provided of teachers carrying out practitioner research for higher degrees. These document the awkwardness the teachers experience in building conceptions of self through reflective work as personal ideas are processed in social space.
\end{abstract}

Keywords: psychoanalysis, practitioner research, drive, desire, reflection

The happiest man on earth would be able to use the Mirror of Erised like a normal mirror, that is, he would look in to it and see himself exactly as he is... It shows us nothing more or less than the deepest desire of our hearts... However, this mirror will give us neither knowledge nor truth. Men have wasted away before it, entranced by what they have seen, or driven mad, not knowing if what it shows is real or even possible. (The late Professor Albus Dumbledore, in Harry Potter and the Philosopher's Stone by J. K. Rowling.)

\section{INTRODUCTION}

This paper seeks to better understand how practitioner research impacts on researchers' sense of whom they are and the world in which they operate. It considers how the stories such researchers tell contribute to an evolving sense of self, but a self implicated in alternative understandings of social worlds. The paper commences by briefly reviewing the status of the individual in successive understandings of practitioner research. It suggests that the self-aware individual of Gadamerian hermeneutics as present in early versions of action research (e.g. Elliott, 1991) has been usurped by an individual rather less sure of his or her personal and social boundaries. A specific theme to be pursued relates to how individuals craft personal experience through socially 
generated discourses. It is suggested that the researcher's subjectivity is a function of this crafting. Yet this process cannot have clear outcomes since a strict separation between the individual and the external world can never be achieved within the discursive terrain of practitioner research. I thus draw an analogy with a psychoanalytic process where the researcher is seen as displaying some similarities to a client engaged in a sequence of psychoanalytic sessions, making sense of their world through talking about it and reflexively pointing to herself through the perspectives revealed. In psychoanalysis the client can be seen as constructing herself through building a story of who she is, a story that guides her in her actions. Likewise reflective writing within practitioner research, reports, generates and deceives, whilst actively redefining the researcher's understanding of her self. The research intervenes in its central object, namely the person carrying out the research.

By contrasting the Freudian terms desire and drive I seek to demonstrate how reflective accounts necessarily miss the reality they seek to portray, yet can stimulate alternative forms of satisfaction that produce new realities. According to Lacan, we are all motivated by desire, a desire that always mistake its object. The narratives we offer within reflective writing never catch up with us, but that need not stop us from trying. And our misses can nevertheless be informative about who we are or where we are. Narratives hold our desires in place even if they do not take us to the place that satisfies them. The stories we tell do not to pin down life for inspection but rather stimulate this life for future growth. Thus reflective writing can be viewed as a stimulator of desire through which our life unfolds. Yet there is also a risk that we begin to believe the stories we tell, as though they provide the final answer. There is a cost for the individual as a result of gearing in to the shared outer world. Through expressing oneself through social codes, procedures etc., personal and social boundaries are reshaped and hence cause a troubling compulsion to settle these boundaries. Žižek suggests that fetishistic satisfaction may be achieved by working to formulae, templates, set pieces, models, regulative frameworks, etc. He sees such behavior as a manifestation of drive where "we get caught into a closed, self propelling loop of repeating the same gesture and finding satisfaction in it" (Žižek, 2006, p. 63).

I draw on work from two of my graduate students with view to outlining how the product of reflective inquiry is shaped by attitudes relating to how the individual constructs images of herself engaging in social worlds. A key element of the courses being followed was a focus on students' understandings of who they were in professional settings and how they built analytical apparatus around accounts of their own actions, towards developing those actions. Both students to be considered explicitly engaged in Lacanian theory within professionally oriented higher degrees. (Aspects of the course processes are described elsewhere (Brown \& Jones, 2001; Brown, Atkinson and England, 2006)). In each case, the Lacanian analysis was targeted at building a more sophisticated account of their subjectivity. The first example describes a senior teacher carrying out practitioner-oriented research for a masters' degree. Here the teacher investigated her own emotional response to a stressful situation with other teachers. It will be suggested that the teacher shifted from seeing reflective inquiry as a therapeutically oriented desire to work through feelings in relation to practice, to seeing the very expression of feelings as a useful tactic in shaping the space in which her practice took place. In the second example, a deputy head teacher from a primary school is caught up in a governmental 
drive to raise school standards. In describing this within her doctoral thesis she finds herself struggling to hold on to her own professional integrity when her own practices are evaluated through a tight externally imposed regulative framework, prompting her to declare, "Why research good practice when the government is telling me what it is?" The analysis of this proposes that the teacher's engagement in her reflective practice is accounted for in speech that oscillates between "sincere" personal reflection and a satisfaction derived through meeting the discursive demands of the framework.

\section{THE HERMENEUTIC ORIENTATION OF EARLY EDUCATIONAL ACTION RESEARCH}

A common understanding of practitioner research in education that has prevailed from the early days of such work situates the researcher as a human reflecting on her immersion in some supposed research environment. The plan, implement and evaluate cycle of Lewin (quoted by Elliott, 1991), is but one of the many manifestations of a Gadamerian hermeneutic approach to research that comprises action, reflection on that action and thus revised action. Such reflections however are not merely a function of action. The situatedness of the researcher in itself impacts on how research is conceived, how events are constructed and then reported through time. Let us commence by focusing briefly on the reflective aspect of this hermeneutic set up.

If I imagine myself as a researcher trying to make sense of the world I will have various thoughts in my mind. At some point, however, I may wish to share my thoughts in words spoken or written. But as I say something I may be more or less disappointed with how my thoughts sound once converted in to words. And through my attempts to reconcile what I thought with what I said, my understanding of the world might then be modified. So when I feel ready to speak again there may be some shift in the way in which I express myself as, in a sense, a different person is speaking. And so on, in a manifestation of the hermeneutic circle where understandings and explanations continue to disturb each other perhaps for as long as I live (Ricoeur, 1981).

In this account of the hermeneutic circle one might suppose an individual who is visible to his or her self and well able to detect the ways in which explanatory words fail and to make adjustments accordingly. The human subject predicated in this understanding is Cartesian. The reflective task is conceptualized in terms of improvement from deficiencies that are self-evident. This version of events, however, lacks some key elements that have emerged in more recent theoretical work where the visibility of oneself to oneself is less evident and where the very notion of self arises through rather different procedures.

Habermasian revisions to this model have pinpointed the failure of language to do an honest job. Language is inherited and is replete with many distortions resulting from particular modes of usage. Such distortions may have arisen, for example, from a government insisting on classifying educational practices in particular ways, or from historically derived modes of description ill-suited to contemporary practices. In such Habermasian perspectives the task of educational research is to detect these distortions and then remove them (Carr \& Kemmis, 1986; Gallagher, 1992; Brown \& Roberts, 2000). Foucault (e.g. 1997), meanwhile, was somewhat unconvinced by Habermas' 
capacity to get a consensus on where such distortions would arise, and shifted the task of research on to the individual resisting domination in its various forms at every opportunity. But, Althusser (1971) had already asked how it could be that individuals spot the discourses that happened to be interpellating them such that they could plot their escape. Althusser also felt that the aspiration to a happy conclusion where everything would be resolved was the biggest fraud of all. More recently Butler (1997), has queried why some discourses stick to individuals through "passionate attachments" whilst others are successfully resisted? Habermas (e.g. 1976) was following Freud's psychoanalysis in supposing that models of understanding were created to facilitate a cure, such as the removal of linguistic distortions to get a better understanding and a release from the torment of deficient rationalizations. A fuller review of these alternatives in the context of educational research is provided elsewhere (Brown \& England, 2004). The next section contrasts Freudian and Lacanian psychoanalysis towards unfolding some alternative accounts of human subjectivity.

\section{THE PSYCHOANALYSIS OF FREUD AND LACAN}

Psychoanalytical thinking is predicated on a reality centered on two people talking in a doctor-client relation for the benefit of the client. This benefit however can be understood in various ways. Freud saw psychoanalytic consultancies as being about achieving a cure, by helping the subject to overcome the distortions. The unconscious was an ever-present phenomenon in such work but, according to Freud, this was like an iceberg making only a small part of itself visible. Freud's work passed through many phases and his influence is diverse, spanning conflicting interpretations. Whilst originally motivated by activating neurological shifts in his patients his legacy might be better understood in retrospect in terms of enabling patients to reassess their pasts with view to opening up and making visible alternative paths for the future. Jacques Lacan (e.g. 2006) was the most famous of those who followed in his path and promoted the shift from bioscientific to narrative emphases in interpreting Freud's work. (Homer, 2005, provides a useful introductory text to Lacan's work.) This contrasted markedly with the approach taken by the ego psychology school in the United States led by émigré analysts including Freud's daughter Anna after his death. In this school the ego was understood as a biological entity to be strengthened in line with a supposed model of good citizenship. The task for Lacan was not to remove supposed distortions in speech in the style of the Freuds and later Habermas but rather to learn from speech to see what it revealed. Such speech was scanned for symptoms of what Lacan called "the truth of desire". Lacan (1990) once famously declared, "I always speak the truth". By this he meant that whatever he, or anyone else, says reveals things about the speaker about which the speaker is not necessarily aware. By understanding how emotional flows of a patient were activated Lacan could, as an analyst, better understand how these shaped the patient's actions that geared into the outer world. In this way actions were explained. These actions, however, were not corrected against a model that was supposed to be correct in advance.

A key element of Lacan's theoretical apparatus was his introduction of the mirror

phase to fill in an apparent gap in Freud's analysis of how the ego is formed (Lacan, 
2006, pp. 75-81). Freud (2002, p. 5) had earlier made the obvious point that: "an adult's sense of self cannot have been the same from the beginning. It must have undergone a process of development". Yet how does this sense of self start to firm up? Further, much of a baby's sense of where her body ends and where the world starts is clearly deluded. Yet what happens to create a more mature account of this, given that surely even adults have their fair share of paranoid delusions about who they are and how the world impacts on their actions? So often Freud's own patients were seen as having developed unhelpful accounts of their histories that piloted them through both the real and imagined obstacles of their lives. Lacan's account of this firming up was seen as being centered on a process akin to the young child looking into a mirror and saying "that's me". Future experiences were then oriented around that sense of self. Yet that self was most certainly a caricature, at best a holding device for an ego that would never be fully complete. And as such this was a deluded sense of self and Lacan had no interest in strengthening this through analysis. In the first Harry Potter movie, for example, Harry sees himself in the Mirror of Erised being comforted by his now dead parents, whilst his friend Ron Weasley sees himself as Quidditch champion and Head Boy. These alternative responses point to an insurmountable gap in the former and a somewhat frivolous one in the latter, neither of which promise a successful therapeutic outcome. The importance of the mirror is rather in what it misses rather than in what it succeeds in reflecting. If the psychoanalyst enables the patient to generate a lot of stories, it may be possible to detect a pattern of territory that gets avoided. Yet further for Lacan (2006), the gap results from the human baby being born too early, committing her to a long dependency on her parents and a susceptibility to the structures that govern her fellow humans. He further suggests that the act of her parents naming her throws her into a complex social network where a place for her has been prescribed in so many ways and the growing human's assertions of self will always be a response to this initial set of expectations. And in turn her responses reflexively create through time an evolving account of the external world to which she continues to respond.

Psychoanalysis is not entirely new to the field of education. Deborah Britzman $(1998,2003)$ has used the work of Anna Freud and Melanie Klein to investigate problematical and ambivalent aspects of teaching. Meanwhile, Pitt and Britzman (2003, p. 756) have argued that a growing body of psychoanalytic educational research, through its emphasis on concepts such as the unconscious, phantasy, affect and sexuality, has worked "to unseat the authorial capabilities of expression to account exhaustively for qualities of experience, to view history as a causal process, and to separate reality from phantasy". Henriques, Hollway, Urwin, Venn and Walkerdine (1984), Shoshona Felman (1987) and others have taken the work of Lacan to explore issues of pedagogy and learning. The authors in a book edited by Sharon Todd (1997) have discussed the place of desire and fantasy in teaching and learning. Other authors broaching this territory include Brown, Hardy and Wilson (1993), Appel (1996), Jagodzinski (2001), Pitt (1998), England and Brown (2001), Atkinson (2002; 2004), Brown and England (2004; 2005), Brown, Atkinson and England (2006) and Brown, Devine, Leslie, Paiti, Sila'ila'i, Umaki, \& Williams (2007).

Such work I suggest specifically supports practitioner research in education where the researcher is often concerned with providing a convincing account of his or her connectedness to the situation he or she is studying. Nevertheless, the purpose of such 
research is often to generate new and fresh perspectives that enable courses of actions that might not have been detected so easily prior to the research. The task may be seen as being to disrupt as well as to confirm what we see. In particular, the reflective research process intervenes in its object. That is, the process of research transforms the human subject it sets out to document. In the sections that follow there is an attempt at using a psychoanalytic frame to provide a way of looking at research data that might open up the possibility of such fresh perspectives where notions of subjectivity become rather more complex.

\section{DESIRE AND DRIVE}

In a recent lecture in London the Lacanian theorist Slavoj Žižek (2005) made a crucial distinction between the Freudian notions of desire and drive. The lecture has now been incorporated into a major work (Žižek, 2006). By contrasting these two notions I seek to distinguish between alternative modes of research enterprise; one in which researcher reflection locates and cultivates a gap between what one says and what one wants to say, and another where the researcher insists on closure between these. I will take each of these terms in turn, explaining their meaning and discussing them in relation to the fitting of research accounts.

\section{Desire}

The notion of desire, perhaps better translated as "wish", explains my motivation in terms of something that I want to acquire, even if I am not quite sure what this thing is exactly. In human sexuality, for instance we may know desire as a promise for the future, an unexplainable and seemingly youthful sparkle that draws us towards someone for a satisfaction not quite specified in advance. Indeed the mystery element is part of the appeal. Desire might also be expressed in relation to how I wish my future life to unfold more generally. Yet this desire and the way it shapes my progress into the future can never quite be captured. There is something beyond my reach that excites me, a surplus beyond that which I can express in words. Or, perhaps alternatively, if I take the desired outcome to be the yardstick, this surplus might be seen as a lack. That is, there is something that prevents me reaching the desired outcome. My explanation of how I could get what I want always misses something. This quandary, of course, applies to my developing sense of self and any work I might do on understanding what that is. I may have a sense of who I am striving to be. Perhaps, however, this is a positive reading of myself that I am trying to actualize in my current actions. I have a sense of the world and how my idealized self fits into this. My sense of where I am going is pleasurably tainted by the promise it holds.

My sense of self, that is, my ego, however, is necessarily a function of how I see the world. My two dual fantasies, of myself, of the world, are inseparable in Lacan's model. These fantasies are processed respectively through what Lacan calls the Imaginary and the Symbolic. My fantasy of self, my Imaginary identification, is the delusory mirror image I have of myself. Meanwhile, my fantasy of the world is processed though the Symbolic, the ideological apparatus that surrounds and engulfs me. Desire is 
present in both of the fantasies as the gap (or the surplus) that separates the fantasy from the reality it seeks to capture. Lacan sees both fantasy and gap (surplus) as positive elements. The fantasy structures the reality that the individual perceives and lives. The gap serves as the motivation (a performative flavouring) that gives the fantasy meaning. For Lacan, there is a world "outside" of these two fantasies, what he calls the Real, but this is an "outside" beyond the scope of the individual's grasp. The Real, by definition, resists any symbolic account. It is "that which remains the same in all possible (symbolic) universes" (Žižek, 2006, p. 26). The mutual formation of Imaginary and Symbolic shapes itself around the resistance of this Real. We can never quite capture ourselves in language but it is this "surplus of the Real over every symbolization that functions as the objectcause of desire" (Žižek, 1989, p. 3).

In fitting a research or scientific model to reality there remains an element of Je ne sais quoi that resists any sense that reality can be successfully processed and fully accounted for through a structural filter. Successive attempts to revise the filter merely alert me to alternative failings. As a practitioner researcher I tell stories of the world yet learn both through the way in which successive stories shape the world but also through the ways in which they seem to fail me. In the Lacanian account proposed the task is not so much concerned with getting the story right (to effect a cure/resolution) but rather it focuses on what can be learnt through making successive substitutions of the stories told, and it is through this that we learn something about the Real:

In a first move the Real is the impossible hard core which we cannot confront directly, but only through the lens of a multitude of symbolic fictions, virtual formations. In a second move, this very hard core is purely virtual, actually non-existent, an $\mathrm{X}$ which can be reconstructed only retroactively, from the multitude of symbolic formations which are "all that there actually is" (Žižek, 2006, p. 24).

It is not uncommon in a process of cyclical action research, for example, to suppose that actions at a later stage of the research might be more in line with expectations. The process of research has enabled the researcher to better predict outcomes to his strategies. Yet the researcher who arrives at these outcomes is a different person. The relationally defined ego is a function of the stories told and how they variously depict the researchers Imaginary and Symbolic identifications. The successive stories that "tell the truth" also transform, the Imaginary, the Symbolic, and perhaps the Real that hosts them.

\section{Drive}

In the first instance Freud introduced "drive" as a central term in human sexuality to ensure a distinction with "instinct" as present in the animal world. For Freud "instinct" is a term that "implies a relatively fixed and innate relationship to an object" (Evans, 1997, p. 46). Drives, however, are contingent on the person's life history and thus vary according to biographical circumstances. But as Žižek was pointing out, drive also contrasts with desire. In Žižek's account, drive is a learned acceptance, or an attitude, that the missing element that activates desire cannot, or need not, be captured. It is the fatalistic acceptance of this loss. As Evans (1997, pp. 46-47) puts it, "the real purpose of the drive is not some mythical goal of full satisfaction, but to return to its circular path, 
and the real source of enjoyment is the repetitive movement of this closed circuit". In Freud's notion of the death drive, for example, desire has been deadened and the model of life that we pursue becomes a substitute for the fantasy that we never quite achieved. The death drive is a sacrifice of desire. It might almost be simplified as "going through the motions" and enjoying it as such, giving up on innovations that might disrupt existing routines and habits. One almost imagines an elderly colleague repeating lectures for years on end and resisting any institutional changes with a weary cry of "we tried that before". Fukuyama's (1992) notion of The End of History caused a theoretical stir a decade ago and might well be seen as an example of such a tendency. That is, the book supposed a final model of human society had been achieved and their was no need for further structural renewal to the liberal democracy that had already arrived and proven itself to be the most resilient of political arrangements. Further, changes could, according to Fukuyama, be seen as mere fine-tuning. The research model understood as a model that had got it right would be replacing the life that it had previously sought to capture. Or perhaps the researcher's investment in the model might be seen as brushing aside evidence that works against this. In this mode work would be undertaken according to the model as though it really was a full account of the reality we are supposedly seeking. There is no gap. Reality is reshaped to fit the model. As such desire and drive can be seen as alternative attitudes and not necessarily sequential modes.

For Lacan, whose psychoanalysis refuses firm distinctions between inside and outside, drive and desire might be seen as two sides of a Möbius strip, or alternative routes on a torus (Lacan, 2002). In a sense they are opposite, yet with a clear path between them. Žižek (2006, p. 7) presents it thus: "let us imagine an individual trying to perform some simple manual task - say grab an object which repeatedly eludes him: the moment he changes his attitude, starting to find pleasure in just repeating the failed task, squeezing the object which, again and again, eludes him, he shifts from desire to drive". How might this movement between attitudes be understood in relation to a practitioner researcher engaged in building analytical apparatus around their professional practice? I offer two examples in which teachers seek to reconcile personal reflections with social demands.

\section{I'M SHY}

Emma, a senior teacher, was reviewing some situations in which she had been talking to colleagues. As part of her research for her masters she had sought to characterize various aspects of her professional self in discussion with fellow course members. She mentioned things such as shyness, conscientiousness, "at the end of ambition", independent, self-contained, kind, sincere, etc. She was also aware of saying such things about herself to colleagues in various situations. The following statement from her reflective diary encapsulates her sense of self in these terms: "My identity comes from a mis-representation, a false persuasion of self that will stay with me as the ideal ego for the remainder of my life. I thus produce a fiction of myself'. In conversation with me and other course members Emma reflected on how in many situations, in her professional life and on the course she described herself to others as "shy". She felt that this had become unhelpfully fixed as part of the fiction of herself that she had identified. 
She reflected on how in listening to others she increasingly found herself asking the question "Why are you telling me this?" In the light of her reflections however she then turned the question around on herself and asked why it was that she was telling others that she was shy. Her conclusion was that it actually resulted in people being different in their attitudes towards her. Perhaps in some ways this was as may be expected. That is, it resulted in people being gentler towards her. There were, however, other aspects to these altered responses. Emma became aware that she sometimes said "I am shy" strategically. If, for example, she declared her shyness in our college sessions it, she realized, became an effective strategy in capturing space for attention and thus being more influential in meetings. As she became aware of herself doing this in college session she turned her attention to how she was acting in a similar fashion within her everyday professional life. And indeed she did locate situations where she was conscious of using overt expressions of unease as an approach to disarming colleagues and opening space for her own actions.

How might this be reconciled with the notions of desire and drive? Emma's statement "I am shy" can be understood in different ways. In Book IX of his Seminars, Lacan (2002, Seminar 1, pp. 8-9) considers the statements "I am lying" and "I think, therefore I am" in terms of how their meaning is carried if they are understood performatively. That is, when they are uttered, the utterance conceals "oblique goals" that transcend the literal content. Perhaps in the first instance "I am shy" is said sincerely. It is a reflective statement that in some ways encapsulates how the teacher understands the situation from her perspective. That is, she sees herself as shy and reports this as part of the reflective landscape she sees as relevant to her research. Or is it even, on this first occasion, in the first utterance, an experiment with a particular social gambit, a performance of a particular understanding of self, perhaps both in the professional situation and in her report of this at a college session? Could it be an example of her "speaking the truth" whilst being unaware of herself doing this? Later, however, Emma became explicitly aware of how it was functioning as a strategy. She realized that it impacted on those around her such that her own space for action was modified, by disarming colleagues, or eliciting sympathy from fellow students on the course.

In her Imaginary identification she understood herself as shy. She did have the option of sticking with this story and reporting on her research environment where her shyness was one of the elements making up this environment. The subjectivity of practitioner research frequently introduces this sort of quandary where there is a need to decide how much a personal assessment fixes the reality of the space being described. Yet her engagement with a Lacanian analysis did result in her asking herself the question "Why am I saying this?" What exactly did she want from the other person? How did her statement impact on the situation being described? And in becoming aware of her statement being more than a statement of fact but instead being a statement that produced a social effect, her sense of the world in which she was operating shifted. That is, her Imaginary and Symbolic identifications, her sense of self, and her sense of the world both shifted. This move however also introduced a gap between the world as predicated by the authentic and sincere statement "I am shy" and the world in which the teacher became aware of this statement's social effect. The recognition by the teacher of this gap offered a lever to make this gap yet wider where the teacher became more aware of the functioning of her own stories and the opportunities that this recognition provided. This resisted Emma's own sense of self where she was shy and had declared that she was at 
the "end of ambition". She began to recognize that she could operate on her own stories about herself and as a result change the research landscape she was surveying. As she later expressed it:

\begin{abstract}
The truth of myself cannot be specified, as it has by its nature a plurality of formations. Of necessity, use of extracts of data is selective, producing 'not one, but many silences and they are an integral part of the strategies that underlie and permeate discourse' (quoting Foucault, 1991, p. 310)... I have been subconsciously selective in what I have absorbed from my cultural contexts through life's journey, taking and weaving particular truths from unconscious desires. Our own ways of being then, link us to the past. Ironically, what is absent is perhaps what I should be interested in, but the ways in which each makes their own out of what they are given, are unpredictable.
\end{abstract}

This quote points to the teacher's awareness of her own ideological immersion and how her Imaginary sense of self has now been processed through the Symbolic order. This points to what Žižek (2006, p. 7) calls the "parallax nature of the gap between desire and drive", a vivacious self image tempered by the cool functioning of the Symbolic order, which then produces transgressive excitements. This parallax is not a "polarity of opposites" since Imaginary and Symbolic are mutually formative (ibid). Desire and drive are implicated as sense of self and sense of world shape up in relation to each other. In switching between "I am shy" being said "sincerely" and it being said as a tactic the teacher is seemingly caught between a desire to live life anew and a drive to stick with locally proven strategies, where this switching is formative of both the individual experimenting (or resigning) and the social space perceived to be housing this oscillation.

This oscillation (or formation) takes another shape in the second example where a teacher is experimenting with an imposed language that, at times, seems deceptively close to more personal modes of expression.

\title{
WHY RESEARCH GOOD PRACTICE WHEN THE GOVERNMENT IS TELLING ME WHAT IT IS?
}

\footnotetext{
Some civil servants are just like my loved ones..., from "Don't worry about the government", Talking Heads '77.
}

In recent years the British government has become very proactive in prescribing policies for schools. Such intervention has been widely interpreted as an assault on the professional integrity of teachers, where teachers themselves are required to police their own practice against externally defined agenda (Bottery \& Wright, 1996; Brown \& McNamara, 2005). Part of the armory of accountability procedures entails schools carrying out self-assessments, governed by the mantra: "the school that knows and understands itself is well on its way to solving any problems it has. The school that is ignorant of its weaknesses, or will not, or cannot face up to them is not well managed" (OfSTED, 2000, p. 150). Detailed procedures were provided, instructing how such assessments were to be carried out in each school.

Brenda is now a Headteacher in a primary school who carried out practitioner research for a professionally oriented doctorate in education. By recording her own 
actions she was able to reflect on how these actions impacted on the definition of her professional role and on the terrain in which this was enacted. Previously as deputy in the same school she had been responsible for self-assessment and this provided the theme for her research. In assessing lessons presented by her staff she followed the procedures. She had also attended three-day training programme for such assessors. Yet Brenda found herself asking whether such procedures could be carried out to the letter. As part of her research she sought to experiment with the template provided to experience and report on the affective dimension of such compliance. Below I offer some extracts from Brenda's reflective writing produced during her attendance at the training sessions. These extracts point to the difficulties she experienced in occupying the official discourse, as it were, whilst reconciling this with more personal reflections made during the practitioner research process. This very distinction between discursive styles, however, proved somewhat tricky as the language of her more personal accounts increasingly made use of the official vocabulary. It became less clear whether her personal use of language embraced or resisted her deepening immersion in the official vocabulary.

\begin{abstract}
Throughout the three days participants were expected to watch a number of videoed extracts of lessons and produce "Lesson Evaluation Forms". Initially the descriptions and marks on a scale 1 to 7 varied considerably. We worked in groups but were asked not to confer initially. I was mildly reprimanded for talking during one video, studious attention was necessary. We were expected to complete our forms and then confer. Some wrote furiously others were more reticent. However, it was in the scoring that the course leader was interested. Each table was asked for a group conclusion, which involved considerable discussion on most tables. The initial video split the group I was working with and some members had to mark the level down, including me. All members had to move some of their marks in one direction or another. Critical argument ensued, "How can you say that?" and "How can that tell you that?" One trainee wrote that, "There are some weaknesses in teaching that mean that some pupils do not understand". Comments from the group included, "How do you know?" and "Do you not find that some pupils don't understand in every lesson?" Indeed, one comment was if they all understood perhaps the lesson would not be stretching enough.

However after much discussion a group decision was reached. All the results were collected, next the trainer gave the "right grades". Members of our group were pleased that we were close and there were a few smug comments of "I told you." This approach continued over five videos of lessons. Interestingly much of the verbal evaluation was unfavorable. A teacher's voice intonation was heavily criticized and a P.E. lesson was "torn to bits". My neighbor stated, "I would never allow my lessons to be recorded as even the good lessons are found at fault." It seemed that negative remarks were easier to give than praise or that the lessons were particularly poor. The latter was not reinforced by the marks, which were generally around average. The official grades were lower to start than the majority given by the groups and no lesson was pronounced as excellent in any area.
\end{abstract}

Such comments point to an apparent demand for compliance in line with tightly specified procedures that were seen as producing the correct results. Brenda felt that her own professionalism was on the line with her conceptions of what constituted good education not fitting well with the new official doctrine. She felt at a complete loss when her then head teacher declared: "Surely you know a good lesson from a bad one?" As Brenda admitted: "This was difficult to answer because simplistically I felt I did". Yet this new 
doctrine seemed to be as much about teachers learning to accept control of their practice as it was about producing better lessons. And the account seemed to point at some of the teachers deriving pleasure from working "correctly" within the exercises. Yet Brenda remained ambivalent:

I appeared to be uncomfortable with the ideology proposed by the government. I wanted to strive to be a better teacher. I felt I had it within my power to work out the best routes to take. Now I was to be told which route to take and how to travel it. How would I accommodate the mismatch between my perceived reality and this proposed ideology? Would it entail a change in my ideological stance? Or could I work with a mismatch?

Yet Brenda's attempt at working through these conflicts led to some surprising results.

One of my (new) roles was Assessment and Evaluation Coordinator in which I was regarded as very efficient. I had computer files full of graphs recording and predicting results in tests. In interviews with the LEA inspector responsible for target setting satisfaction with the analysis of results was always forthcoming. Official reports of visits always left me with a feeling of satisfaction. I felt that I was doing a good job... Indeed the document contained a number of health warnings, such as "it is important to recognize that data analyses provide few, if any, answers" and "despite all the fuss about targets and the use of data, it is important to remember that children do not grow taller by being measured". My cynicism was probably softened by these remarks. I actually enjoy playing with numbers and data, so after voicing the negative aspects to the course leader I completed the necessary work satisfactorily. In fact my diary entries say little about this section of the training. The effect of performance tables on teacher and children was important to me and I had voiced my opinions, which were met with nods from other managers. ...(but) here I (had) accepted an imposed idea that I felt did not really address educational improvement. Yet I gained pleasure through the praise I received about my competence.

These thoughts point to an increasingly fatalistic acceptance of the new strictures where small pleasures are derived from getting the game right or finding space for "playing with numbers". Brenda is not so much embracing or resisting the strictures as becoming part of them at practical level whilst still attempting to distance herself from them at an intellectual level. Her very identity became a function of governmental apparatus where individual and social could no longer be readily distinguished. Žižek (2006, p. 6) pinpoints how the individual presents herself as a manifestation of the social order:

The field of social practices and socially held beliefs, is not simply on a different level from individual experience, but something to which the individual has to relate, which the individual himself has to experience as an order which is minimally "reified", externalised ... the gap between the individual and the "impersonal" social dimension is to be inscribed back within the individual himself: this "objective" order of the social substance exists only insofar as individuals treat it as such, relate to it as such (Žižek's emphasis).

Brenda had seemingly become part of the social structure from which she was seeking to distance herself: "My first performance management objective was to gain accreditation in school self-evaluation. This was to enable me to evaluate teachers' performance for 
performance management and for the school's general improvement". This extract is quite striking in its resplendent use of the official discourse. Words such as "performance management", "accreditation", "school self-evaluation", and "improvement" are sprinkled liberally. Yet it is not clear how much irony is intended. In being obliged to use such terms so often in her professional life, where her own performance is evaluated through a particular style of usage, is it possible for Brenda to remain distanced from the words that she uses? Žižek (1989, pp. 27-33) had earlier argued that contemporary ideological structures only function successfully if subjects act with a certain degree of cynical distance. Ideological functioning, he suggests, is premised on a growing gap between our discursive production and associated activity, there is no necessary relationship between reality and its symbolization (cf. Laclau and Mouffe, 2001). Ideologies incorporate their own cynicism in advance since such openness undermines attempts to distance oneself and be critical from a supposed outside.

(I)n different historical circumstances it would undoubtedly have subversive effects; today however, in the era of cynicism, ideology can afford the secret of its functioning (its constitutive idiocy, which traditional, pre-cynical ideology had to keep secret) without in the least affecting its efficiency (Žižek, 1996, p. 200, Žižek’s emphasis).

Meanwhile, full on, face value compliance, he has argued, leads to a collapse of the structure. He cited the example of Jaroslav Hašek's The Good Soldier Švejk, in which a soldier creates havoc by following rules to the letter (Žižek, 1997, p. 22). (This character might be seen as a prototype for Forest Gump also discussed by Žižek (1996, pp. 200201).) Cynical distance, he had further argued, is a way "to blind ourselves to the structuring power of ideological fantasy: even if we do not take things seriously, even if we keep an ironical distance, we are still doing them (Žižek, 1989, p. 33, Žižek's emphasis). As Butler (2005, (p. 5) explains in his account of Žižek's notion of fantasy: "It is not so much in what we believe as in our external practices that fantasy is to be found." In situations of ideological immersion we have no choice other than to assume a cynical or ironical distance that sustains at a practical level the ideology perhaps being resisted at an intellectual level. Yet, Žižek (1996, pp. 207-208) later teases out a more precise distinction between the two positions of cynic or ironist and considers the potential for movement between these. He suggests that these two positions each activate their own potential deadlock:

The cynic reduces ideological chimeras to raw reality, he is in search of the real ground of elevated ideological fictions; whereas the ironist entertains a suspicion that perhaps reality itself is not real but always already structured as a fiction, dominated, regulated by an unconscious fantasy. Each of these two attitudes involves its own trap; the cynic's, a naive belief in ultimate reality outside the cobweb of symbolic fictions; the ironist's, the opposite: the reduction of reality itself to a fiction.

Brenda had attempted to play it straight but with seditious intent in a situation that seemingly presented itself as a totalitarian coup of the discursive territory. That is, she sought to follow the rules to the letter to see if such tactics could rumble the core by revealing in a direct way their ridiculous functioning if pursued with mechanical compliance. Yet the very structures promoted a cynical distance in a number of ways. For example, by offering health warnings about their own shortcomings, or by occupying 
positions of "common sense" that so obviously concealed strategic moves, or by distracting her with pleasurable tasks where she could achieve localized success, Brenda could not fail to move to and fro between consent and denial, but in so doing she enacted at a practical level the very structures that she sought to discredit at an ideological level. She would have needed either monumental cynical powers, or fantastic powers of compliance, to not assume a cynical or ironical position. Brenda's desire to hold on to her own professional aspirations was translated into a social language shaped around this new order, which in a sense fixed the parameters and thereby supported the success of the new social order. And the pursuit within these parameters became the new source of pleasure, not quite as pure as the driven snow, but driven nonetheless.

\section{CONCLUSION}

So then, what does a reflective researcher see when they look into the mirror and how much control do they have over what they see? Lacan's mirror locates an Imaginary identification that we should be cautious in promoting. Nevertheless, an examination of how the mirror works can be quite informative. The reflective stories that the researcher tells provide material for analysis. Yet the "reflections" are performative, not mere neutral reflections. They represent engagement in the social life being reported. Analysis can be directed at examining the nature of the truth told and how this truth might be seen as concealing or activating other stories. The status of this story needs to be considered carefully insofar as there are difficulties in supposing that the story is in some way representative of the person. The story can also be seen as performative or generative of the reality it seeks to depict. The story can have material effects without necessarily having positive content. The story can also be seen as a mask. The chain of writings can create an illusion that there is an underlying content with an isomorphic relation between signifiers and signifieds. The articulation of multiple reflective extracts perhaps creates an illusion that they surround a singular identity.

It is through this route that Lacan differs from Habermas and his particular route from Freud. As seen, whilst Habermas like Freud aspires to some sort of resolution, Lacan's account lacks Freud's victory narratives. Or rather, for Lacan, psychoanalytic work is more of a continual and permanent aspect of self-realizing, or a recurrent response to perceived expectations. The gap is never closed. This process comprises an on-going redefinition of self and of the world that shapes itself around that self. In this account human identity is never fixed and furthermore you are never able to say what you want to say because the words are not your own. Or at least ownership is in a state of permanent dispute. This drives the subject to keep on talking, to offer yet more accounts, to re-frame her intentions again and again successively, always anticipating the true version of her life but never quite getting there. And it is in this re-writing that her sense of self evolves through the narratives that she offers, motivated by desires that aspire to renewal and drives that find pleasure in repetition.

As has been seen in the two examples there is some slippage between language used in personal reflection and that used in socially constructed space. This pointed to some lack of clarity about whether language was being used sincerely or not. Indeed the term "sincerity" implies a self-knowledge that may not have been readily available to the 
individuals concerned. In the first example, the teacher took time to reflect on how a feeling of unease with colleagues gave rise to an expression of this unease, which then impacted on the space she had seen as the source of that unease. And through this route the nature of the uneasiness was transformed. There was a time dimension through which the feeling was recast as a tool. This tool shaped a new reflection in which the seeming dichotomy of sincere or not was effaced since the expression, combined with reflection on it, had changed both the individual and the space she occupied. In the second example the official guidance kept tricking the teacher in to believing that she was already using the required language. The teacher was attempting to distance herself from complete immersion in the official discourses but found herself sucked in through a need to use a language and associated practices that were officially sanctioned in her communication with colleagues. The new documentation had also masked itself in a language of common sense. The virtue of new practices was presented as self-evident.

In both situations the teachers became aware of how their use of language transformed the parameters that had given rise to this use and as a result the teachers became caught in an uncertain space between what Žižek defines as cynical and ironical positions. Nevertheless, the individual can achieve pleasure (jouissance) through experimenting with this discursive material and with one's relation to it. And it is the pursuit of this pleasure that shapes the portrayals of self that gear into the outer world. In the two examples the source of jouissance became a function of the mode of participation in the linguistic games being played out in the social domain, rather than as seemed at the outset, being about feeling more at ease in professional interactions in the first example, or promoting quality lessons in the second. Desire shifted to drive. For Emma the act of saying "I'm shy" became a commodification of emotional exchange that stimulated alternative pleasures. Brenda, meanwhile, by attempting to distance herself intellectually from the official discourses found satisfaction in this attempted distancing which was always impossible at a practical level.

In any enunciation, however, there can be a lack of clarity as to from where the subject is speaking. What fantasy does the speaker have of her own speaking subject and of whom she is speaking to? And what does she think that that listener expects? And thus the attitude shifts with this sliding between subject positions variously, ironic, cynical, sincere, correct, deluded, etc. The very enunciation activates a shift in who is speaking. The speaker has an imaginary sense of self of speaking from a position to a position but both positions are multiply contingent. We are cushioned such that our rationales for what we are doing are always at some distance from the actuality of our actions since "our vision of reality is anamorphically distorted ... which accounts for the very multiplicity of appearances of the same underlying Real" (Žižek, 2006, p. 24, Žižek's emphasis). "This means that, ultimately, the status of the Real is purely parallactic and, as such, non-substantial; is (sic) has no substantial density in itself, it is just a gap between two points of perspective, perceptible only in the shift from one to the other (ibid). As Žižek (1996, p. 194) reflects: "when I speak, I always constitute a virtual place of enunciation from which I speak, yet this is never directly "me'". There is a difference between what you say and what you do but, as seen, for Žižek, it is what you do that delineates the fantasies that govern who you are but the form of your behavior escapes you, the mirror is cracked sending signals at unexpected angles, and, meanwhile, you can never be quite sure how what you do will be interpreted by others. "The lesson to be 
drawn from this concerning the social field is above all that belief, far from being an "intimate', purely mental state, is always materialized in our effective social activity: belief supports the fantasy which regulates social reality" (Žižek, 1989, p. 36).

\section{REFERENCES}

Althusser, L. (1971). Ideology and ideological state apparatuses. London: New Left Books.

Appel, S. (1996). Positioning subjects: psychoanalysis and critical educational studies. Westport: Bergin \& Garvey.

Atkinson, D. (2002). Art in education: identity and practice. Dordrecht: Kluwer.

Atkinson, D. (2004). Theorising how student teachers form their identities in Initial Teacher Education. British Education Research Journal, 30(3), 379 - 394.

Bottery, M., \& Wright, N. (1996). Cooperating in their own deprofessionalisation? On the need to recognise the "public" and "ecological" roles of the teaching profession. British Journal of Education Studies, 44(1), 82-98.

Britzman, D. (1998). Lost subjects, contested objects. Albany: State University of New York Press.

Britzman, D. (2003). After education. (Albany, State University of New York Press.

Brown, T., Devine, N., Leslie, E. Paiti, M., Sila'ila'i, E., Umaki, S. \& Williams, J. (2007) Reflective engagement in cultural history: A Lacanian perspective on Pasifika teachers in New Zealand, Pedagogy, Culture and Society, 15(1), 107-119.

Brown, T., Hardy, T., \& Wilson, D. (1993). Mathematics on Lacan's couch. For the Learning of Mathematics, 13(1), 11-14.

Brown, T., \& Jones, L. (2001). Action research and postmodernism: congruence and critique. Buckingham: Open University Press.

Brown, T., \& McNamara, O. (2005) New teacher identity and regulative government: the discursive formation of primary mathematics teacher education. New York: Springer.

Brown, T. \& Roberts, L. (2000). Memories are made of this: temporality and practitioner research', British Educational Research Journal, 26(5), 649-659.

Brown, T., \& England, J. (2004) Revisiting emancipatory teacher research: a psychoanalytic perspective, British Journal of Sociology of Education, 25(1), 67-80.

Brown, T., \& England, J. (2005). Identity, narrative and practitioner research, Discourse: studies in the cultural politics of education, 26(4), 443-458.

Brown, T., Atkinson, D., \& England, J. (2006). Regulative discourses in education: a Lacanian perspective. Bern Switzerland: Peter Lang publishers.

Butler, J. (1997). The psychic life of power. Stanford: Stanford University Press.

Butler, R. (2005). Slavoj Žižek: Live Theory. London: Continuum.

Carr, W., \& Kemmis, S, (1986). Becoming critical: knowing through action research. London: Falmer.

Elliott, J. (1991). Action research for educational change. Buckingham: Open University Press.

England, J., \& Brown, T. (2001). Inclusion, exclusion and marginalisation, Educational Action Research, 9(3) 335-371.

Evans, D. (1997). Dictionary of Lacanian psychoanalysis. London: Routledge.

Felman, S. (1987). Jacques Lacan and the adventure of insight: psychoanalysis in contemporary culture. Cambridge, MA: University of Harvard Press.

Foucault, M. (1991). The Foucault reader. P. Rabinow (Ed.) Harmondsworth: Peregrine.

Foucault, M. (1997). The ethics of the concern of the self as a practice of freedom. In Ethics, trans. P. Rabinow. London: Penguin.

Freud, S. (2002). Civilisation and its discontents. London: Penguin.

Fukuyama, F. (1992). The end of history and the last man. London, Penguin.

Gallagher, S. (1992) Hermeneutics and education. Albany: State University of New York Press.

Habermas, J. (1976). Systematically distorted communication. In P. Connerton, Critical sociology (pp. 348361). Harmondsworth: Penguin. 
Henriques, J., Hollway, W., Urwin, C., Venn, C., \& Walkerdine, V. (1984). Changing the subject. London: Methuen.

Homer, S. (2005). Jacques Lacan. London: Routledge.

Jagodzinski, J. (2001). Pedagogical desire. Westport: Bergin and Garvey.

Lacan, J. (2002). The seminar of Jacques Lacan. Book IX. Identification. Trans C. Gallagher. Privately produced by translator.

Lacan, J. (2006). Ecrits. New York: Norton.

Lacan, J. (1990). Television. New York: Norton.

Laclau, W. \& Mouffe, C. (2001). Hegemony and socialist strategy. London: Verso.

OfSTED (2000). Handbook for inspection. London: OfSTED.

Pitt, A. (1998). Qualifying resistance: some comments on methodological dilemmas, International Journal of Qualitative Studies in Education, 11(4), 535-554.

Pitt, A., \& Britzman, D. (2003). Speculations on qualities of difficult knowledge in teaching and learning; an experiment in psychoanalytic research. International Journal of Qualitative Studies in Education, 16(6), 755-776.

Ricoeur, P. (1981). Hermeneutics and the human sciences. Cambridge: Cambridge University Press.

Todd, S. (Ed.) (1997). Learning desire. New York: Routledge.

Žižek, S. (1989). The sublime object of ideology. London: Verso.

Žižek, S. (1996). The indivisible remainder. An essay on Schelling and related matters. London: Verso.

Žižek, S. (1997). The plague of fantasies. London: Verso.

Žižek, S. (2005). Respect for otherness? No thanks, Lecture at Birkbeck College, London, 20th May 2005.

Žižek, S. (2006). The parallax view. Cambridge MA: MIT Press. 